\title{
EFFECT OF TEMPERATURE ON THE ACTION OF GALGIUM ON ISOLATED RABBIT ILEUM
}

\author{
G. ACHARI AND C. N. SINHA \\ Universily Depariment of Pharmacology, Prince of Wale's Medical College, Patna, India
}

Received for publication May 6, 1968

Buglia (I) had observed that absence of calcium suppresses the rythmic contractions of intestine. Vanysek (2) stated that calcium chloride stimulates the circular and relaxes the longitudinal muscle in the excised intestine of the cat. Robertson (3) reported that deficiency of calcium produces hypertonicity of the colon. Later Jhonson (4) found that cooling and reduction of calcium ion reduced the spontaneous output of acetylcholine from the nerve endings in the wall of the intestine. Burn and Gibbons (5) had noted that the inhibitory effect of stimulating the periarterial nerves on the pendular movements of a loop of rabbit ileum depends on the concentration of calcium present. The inhibition due to stimulation was greatly increased, when the calcium concentration was raised from below normal to the normal concentration in the tyrode solution.

Literature about the effect of calcium at different temperatures is not readily available. In the present work action of calcium ion on isolated rabbit ileum has been investigated at different temperatures.

\section{MATERIALS AND METHODS}

Healthy adult rabbits were killed by blow on the head and bled to death. The ileum was remove immediately and mounted in three isolated tissue baths ( $50 \mathrm{ml}$ capacity) by the magnus method and the movements recorded on smoked drums. The temperatures in the baths were maintained at $24^{\circ}, 30^{\circ}$ and $36^{\circ} \mathrm{C}$. respectively. The weight of drugs were calculated as their salt.

\section{RESULTS}

It was observed that at $24 \mathrm{C}$ the addition of $80 \mu \mathrm{g} / \mathrm{ml}$ of calcium produced a slight stimulation in intestinal movements as indicated by the rise in tone (Fig. 1). One
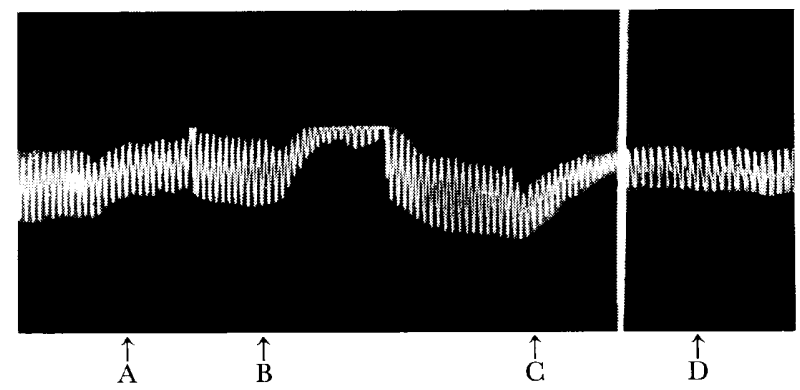

FIG. 1. Effect of calcium on the pendular movement of the rabbit gut at $24 \mathrm{C}$. (A) $80 \mu \mathrm{g} / \mathrm{ml}$ (B) $160 \mu \mathrm{g} / \mathrm{ml}$ (C) $320 \mu \mathrm{g} / \mathrm{ml}$ (D) $320 \mu \mathrm{g} / \mathrm{ml}$ of $\mathrm{Ca}$ after $10 \mu \mathrm{g}$ of atropine in bath $(50 \mathrm{ml}$ capacity). 


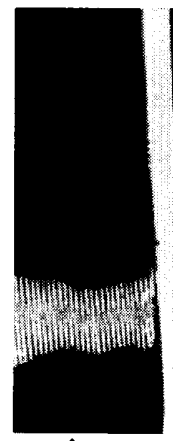

A

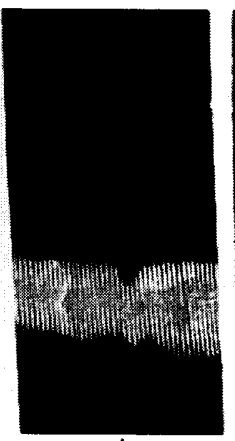

$\uparrow_{\mathbf{B}}^{\uparrow}$

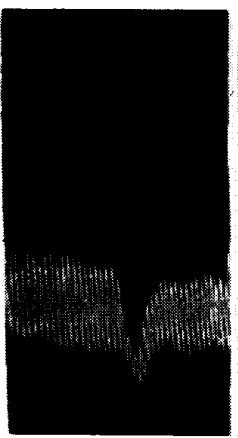

$\stackrel{\uparrow}{\mathrm{C}}$

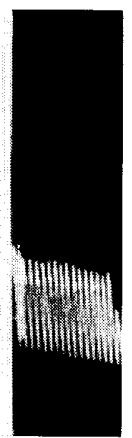

D

FIG. 2. The effect of calcium on rabbit gut at $30^{\circ} \mathrm{C}$. (A) $80 \mu \mathrm{g} / \mathrm{ml}$ $\begin{array}{llll}\text { (B) } 160 \mu \mathrm{g} / \mathrm{ml} & \text { (C) } 320 \mu \mathrm{g} / \mathrm{ml} & \text { (D) } 320 \mu \mathrm{g} / \mathrm{ml} \text { of } \mathrm{Ca} \text { after } 0.3\end{array}$ $\mathrm{mg}$ of propranolol in bath $(50 \mathrm{ml}$ capacity).

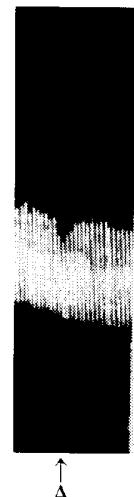

A

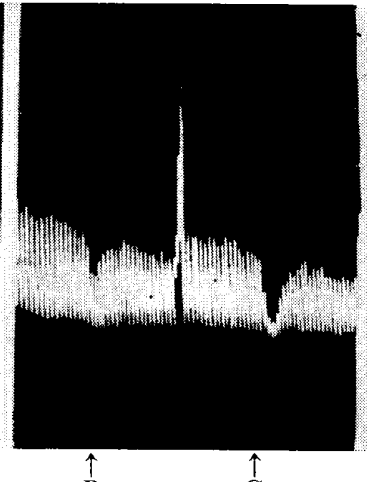

B

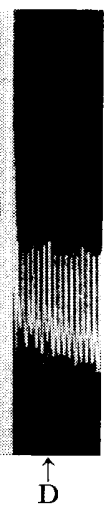

Fig. 3. The effect of calcium on pendular movement of rabbit gut at $366^{\circ}$ C. (A) $80 \mu \mathrm{g} / \mathrm{ml}$ (B) $160 \mu \mathrm{g} / \mathrm{ml}$ (C) $320 \mu \mathrm{g} / \mathrm{ml}$ (D) 320 $\mu \mathrm{g} / \mathrm{ml}$ of $\mathrm{Ca}$ after $0.3 \mathrm{mg}$ of propranolol in bath $(50 \mathrm{ml}$ capacity).

hundred and sixty $\mu \mathrm{g} / \mathrm{ml}$ and $320 \mu \mathrm{g} / \mathrm{ml}$ of the ion however produced a marked rise in the tone of the gut which was completely prevented by the prior administration of $10 \mu \mathrm{g}$ of atropine in the bath.

Both at $30^{\circ}$ and $36 \mathrm{C}$, the addition of $80 \mu \mathrm{g} / \mathrm{ml}$ of calcium produced a detectable inhibition of the intestinal movement. One hundred and sixty $\mu \mathrm{g} / \mathrm{ml}$ and $320 \mu \mathrm{g} / \mathrm{ml}$ of the substance produced a definite but shortlasting inhibition of the gut (Figs. 2 and 3). This inhibition was completely prevented by $0.3 \mathrm{mg}$ of propranolol present in the bath.

\section{DISCUSSION}

In the present work the authors have been able to demonstrate the spasmodic action of calcium on the gut at $24 \mathrm{C}$. Dikshit (6) had found that in guinea-pig, rabbit and dog all parts of the gastrointestinal tract, particularly the samll intestine, could synthesize acetylcholine. Feldberg and Lin (7) had demonstrated the spontaneous release of acetylcholine from the intestinal wall of rabbit. As mentioned earlier, Jhonson (4) had observed that cooling to $25 \mathrm{C}$ and reduction of calcium ion reduced the spontaneous 
output of acetylcholine from the nerve endings in the wall of intestine. The spasmodic action of calcium in the present work might be due to liberation of acetylcholine. The present observation can also be explained by the hypothesis of Burn and Rand $(8,9)$. They have given reasons for thinking that within the same sympathetic postganglionic fibre acetylcholine is released first and this in its turn releases noradrenaline. At $24^{\circ} \mathrm{C}$ this latter event might not take place, and due to the lack of inactivation by esterases the acetylcholine liberated might accumulate and stimulate the gut movement. Of course the explanation has yet to be substantiated by facts.

The more interesting observation in the current study was the definite demonstration of intestinal inhibition by calcium at $30^{\circ}$ and $36^{\circ} \mathrm{C}$. That this inhibition of intestinal movement is due to the release of catecholamines is suggested by the effectiveness of propranolol in preventing the response. Earlier, Douglas and Rubin $(10,11)$ had demonstrated that calcium is essential for the release of catecholamines from adrenal medulla. Recently Jannus, Miele and Rubin (12) had also demonstrated the blockade of calcium evoked release of catecholamines by propranolol.

\section{SUMMARY}

1. Calcium is a spasmodic to gut at $24 \mathrm{C}$ and this action is probably due to release of acetylcholine.

2. At $30^{\circ}$ and $36^{\circ} \mathrm{C}$, calcium causes inhibition of rabbit ileum through the release of catecholamines. This release of catecholamines is completely prevented by propranolol.

\section{REFERENCES}

1) Buglia, G.: Z. Biol. 55, 343 (1911)

2) VAnYseK, F.: Biochem. Z. 67, 221 (1914)

3) Robertson, E.C.: University of Toronto Series, Path. Series, 79 (1938)

4) Jhonson, E.S.: Bril. J. Pharmac. Chemother. 21, 555 (1963)

5) Burn, J.H. and GibBons, W.R.: Ibid. 22, 540 (1964)

6) Diкshit, B.B.: J. exp. Physiol. 28, 243 (1938)

7) Feldberg, W. and Lin, R.C.Y.: J. Physiol. 109, 475 (1949)

8) Burn, J.H. and Rand, M.J.: Nature, Lond. 184, 163 (1959)

9) Bunn, J.H. and Rand, M.J.: A. Rev. Pharmac. 5, 163 (1965)

10) Douglas, W.W. and Rubin, R.P.: J. Physiol. 159, 40 (1961)

11) Douglas, W.W. and Rubin, R.P.: Ibid. 167, 288 (1963)

12) Jaanus, S.D. and Miele, E. and Rubin, R.P.: Brit. J. Pharmac. Chemother. 31, 319 (1967) 